\title{
U.S. Geological Survey Input-Data Forms for the Assessment of the Upper Jurassic Bossier Formation, U.S. Gulf Coast, 2016
}

Open-File Report 2018-1134 



\section{U.S. Geological Survey Input-Data Forms for the Assessment of the Upper Jurassic Bossier Formation, U.S. Gulf Coast, 2016}

By Stanley T. Paxton, Janet K. Pitman, Scott A. Kinney, Nicholas J. Gianoutsos, Ofori N. Pearson, Katherine J. Whidden, Russell F. Dubiel, Christopher J. Schenk, Lauri A. Burke, Timothy R. Klett, Heidi M. Leathers-Miller, Tracey J. Mercier, Seth S. Haines, Brian A. Varela, Phuong A. Le, Thomas M. Finn, Stephanie B. Gaswirth, Sarah J. Hawkins, Kristen R. Marra, and Marilyn E. Tennyson

Open-File Report 2018-1134 


\title{
U.S. Department of the Interior \\ RYAN K. ZINKE, Secretary
}

\author{
U.S. Geological Survey \\ James F. Reilly II, Director
}

U.S. Geological Survey, Reston, Virginia: 2018

For more information on the USGS - the Federal source for science about the Earth, its natural and living resources, natural hazards, and the environment-visit https://www.usgs.gov or call 1-888-ASK-USGS.

For an overview of USGS information products, including maps, imagery, and publications,

visit https://store.usgs.gov.

Any use of trade, firm, or product names is for descriptive purposes only and does not imply endorsement by the U.S. Government.

Although this information product, for the most part, is in the public domain, it also may contain copyrighted materials as noted in the text. Permission to reproduce copyrighted items must be secured from the copyright owner.

Suggested citation:

Paxton, S.T., Pitman, J.K., Kinney, S.A., Gianoutsos, N.J., Pearson, O.N., Whidden, K.J., Dubiel, R.F., Schenk, C.J., Burke, L.A., Klett, T.R., Leathers-Miller, H.M., Mercier, T.J., Haines, S.S., Varela, B.A., Le, P.A., Finn, T.M., Gaswirth, S.B., Hawkins, S.J., Marra, K.R., and Tennyson, M.E., 2018, U.S. Geological Survey input-data forms for the assessment of the Upper Jurassic Bossier Formation, U.S. Gulf Coast, 2016: U.S. Geological Survey Open-File Report 2018-1134, 48 p., https://doi.org/10.3133/ofr20181134.

ISSN 2331-1258 (online) 


\section{Contents}

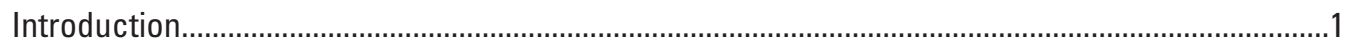

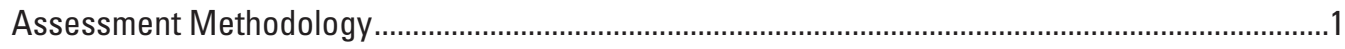

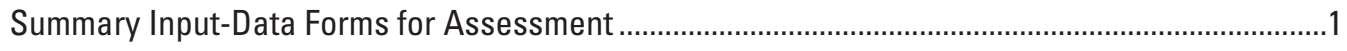

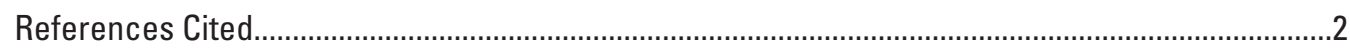

\section{Tables}

1. Input parameters for the Bossier Eastern Shelf Sandstone Gas and Oil Assessment Unit (50490118), Onshore U.S. Gulf Coast Province...........................................................

2. Input parameters for the Bossier Western Shelf Sandstone Gas Assessment Unit (50490119), Onshore U.S. Gulf Coast Province ...................................................................19

3. Input parameters for the Bossier Shale Continuous Gas Assessment Unit (50490163), Onshore U.S. Gulf Coast Province ....................................................................35 



\section{U.S. Geological Survey Input-Data Forms for the Assessment of the Upper Jurassic Bossier Formation, U.S. Gulf Coast, 2016}

By Stanley T. Paxton, Janet K. Pitman, Scott A. Kinney, Nicholas J. Gianoutsos, Ofori N. Pearson, Katherine J. Whidden, Russell F. Dubiel, Christopher J. Schenk, Lauri A. Burke, Timothy R. Klett, Heidi M. Leathers-Miller, Tracey J. Mercier, Seth S. Haines, Brian A. Varela, Phuong A. Le, Thomas M. Finn, Stephanie B. Gaswirth, Sarah J. Hawkins, Kristen R. Marra, and Marilyn E. Tennyson

\section{Introduction}

In 2016, the U.S. Geological Survey (USGS) completed an updated assessment of undiscovered, technically recoverable oil and gas resources in the Upper Jurassic Bossier Formation of the onshore U.S. Gulf Coast Province (Paxton and others, 2017). The Bossier Formation was assessed using both the standard continuous (unconventional) and conventional methodologies established by the USGS for three assessment units (AUs): (1) Bossier Eastern Shelf Sandstone Gas and Oil AU, (2) Bossier Western Shelf Sandstone Gas AU, and (3) Bossier Shale Continuous Gas AU. A fourth assessment unit, the Upper Jurassic Downdip Continuous Gas AU, was also defined but was not quantitatively assessed because of limited well data within the extent of the AU. The revised assessment resulted in total estimated mean resources of 2.9 billion barrels of oil, 108.6 trillion cubic feet of gas, and 1.1 billion barrels of natural gas liquids. The purpose of this report is to provide supplemental documentation of the input parameters used in the USGS 2016 Bossier Formation assessment.

\section{Assessment Methodology}

The USGS uses two different peer-reviewed methodologies to assess continuous (unconventional) and conventional resource accumulations. Continuous resource accumulations are defined as oil and (or) natural gas that have been generated from thermally mature source rock and have remained within or adjacent to the pod of active source rock. The continuous resources methodology focuses on uncertainties related to the average drainage area of wells and the average estimated ultimate recoveries of wells, in addition to the projection of future success ratios (Charpentier and Cook, 2012). In contrast, conventional petroleum resources are defined where oil and (or) natural gas have migrated into structural and (or) stratigraphic traps and are buoyant upon water. Conventional resource assessments therefore focus on the numbers and sizes of undiscovered conventional accumulations (Klett and others, 2005). Despite differences in the input parameters, both methodologies result in probabilistic estimates of undiscovered, technically recoverable petroleum resources. Supplemental documentation regarding these resource methodologies can be found in multiple published reports (Klett and Charpentier, 2003; Crovelli, 2005; Klett and others, 2005; Klett and Schmoker, 2005; Schmoker, 2005; Schmoker and Klett, 2005; Charpentier and Cook, 2012).

\section{Summary Input-Data Forms for Assessment}

The input-data forms for the three quantitatively assessed Bossier Formation AUs are provided in tables 1-3. 


\section{References Cited}

Charpentier, R.R., and Cook, T.A., 2012, Improved USGS methodology for assessing continuous petroleum resources, ver. 2.0: U.S. Geological Survey Data Series 547, 22 p. [Also available at https://pubs.er.usgs.gov/publication/ds547.]

Crovelli, R.A., 2005, Analytic resource assessment method for continuous petroleum accumulations-The ACCESS assessment method, chap. 22 of USGS Southwestern Wyoming Province Assessment Team, Petroleum systems and geologic assessment of oil and gas in the Southwestern Wyoming Province, Wyoming, Colorado, and Utah: U.S. Geological Survey Digital Data Series DDS-69-D, 10 p. [Also available at https://pubs.usgs.gov/dds/dds-069/dds-069-d/REPORTS/69_D_CH_22.pdf.]

IHS Markit ${ }^{\mathrm{TM}}$, 2016, U.S. well history and production database: Englewood Colo., IHS Markit, accessed August 2016, at http:// www.ihsenergy.com. [Also available from IHS Markit, 15 Inverness Way East, Englewood, CO 80112.]

Klett, T.R., and Charpentier, R.R., 2003, FORSPAN model users guide: U.S. Geological Survey Open-File Report 2003-354, 37 p. [Also available at https://pubs.er.usgs.gov/publication/ofr03354/.]

Klett, T.R., and Schmoker, J.W., 2005, U.S. Geological Survey input-data form and operational procedure for the assessment of continuous petroleum accumulations, 2002, chap. 18 of USGS Southwestern Wyoming Province Assessment Team, Petroleum systems and geologic assessment of oil and gas in the Southwestern Wyoming Province, Wyoming, Colorado, and Utah: U.S. Geological Survey Digital Data Series DDS-69-D, 8 p. [Also available at https://pubs.usgs.gov/dds/dds-069/dds-069-d/ REPORTS/69_D_CH_18.pdf.]

Klett, T.R., Schmoker, J.W., and Charpentier, R.R., 2005, U.S. Geological Survey input-data form and operational procedure for the assessment of conventional petroleum accumulations, chap. 20 of USGS Southwestern Wyoming Province Assessment Team, Petroleum systems and geologic assessment of oil and gas in the Southwestern Wyoming Province, Wyoming, Colorado, and Utah: U.S. Geological Survey Digital Data Series DDS-69-D, 8 p. [Also available at https://pubs.usgs.gov/dds/dds-069/ dds-069-d/REPORTS/69_D_CH_20.pdf.]

Nehring Associates, 2016, The significant oil and gas fields of the United States database [includes data current as of December 31, 2014]: Colorado Springs, Colo., Nehring Associates, database. [Available from Nehring Associates, P.O. Box 1655, Colorado Springs, CO 80901.]

Paxton, S.T., Pitman, J.K., Kinney, S.A., Gianoutsos, N.J., Pearson, O.N., Whidden, K.J., Dubiel, R.F., Schenk, C.J., Burke, L.A., Klett, T.R., Leathers-Miller, H.M., Mercier, T.J., Haines, S.S., Varela, B.A., Le, P.A., Finn, T.M., Gaswirth, S.B., Hawkins, S.J., Marra, K.R., and Tennyson, M.E., 2017, Assessment of undiscovered oil and gas resources in the Bossier Formation, U.S. Gulf Coast, 2016: U.S. Geological Survey Fact Sheet 2017-3015, 2 p. [Also available at https://pubs.er.usgs. gov/publication/fs20173015.]

Schmoker, J.W., 2005, U.S. Geological Survey assessment concepts for continuous petroleum accumulations, chap. 13 of USGS Southwestern Wyoming Province Assessment Team, Petroleum systems and geologic assessment of oil and gas in the Southwestern Wyoming Province, Wyoming, Colorado, and Utah: U.S. Geological Survey Data Series DDS-69-D, 7 p. [Also available at https://pubs.usgs.gov/dds/dds-069/dds-069-d/REPORTS/69_D_CH_13.pdf.]

Schmoker, J.W., and Klett, T.R., 2005, U.S. Geological Survey assessment concepts for conventional petroleum accumulations, chap. 19 of USGS Southwestern Wyoming Province Assessment Team, Petroleum systems and geologic assessment of oil and gas in the Southwestern Wyoming Province, Wyoming, Colorado, and Utah: U.S. Geological Survey Data Series DDS-69-D, 6 p. [Also available at https://pubs.usgs.gov/dds/dds-069/dds-069-d/REPORTS/69_D_CH_19.pdf.] 
Table 1. Input parameters for the Bossier Eastern Shelf Sandstone Gas and Oil Assessment Unit (50490118), Onshore U.S. Gulf Coast Province.

[Well production data from IHS Markit ${ }^{\mathrm{TM}}$ (2016). BCFG, billion cubic feet of gas; MMCFG, million cubic feet of gas; CFG, cubic feet of gas; MMBO, million barrels of oil; MMBOE, million barrels of oil equivalent; BO, barrel of oil; BLIQ, barrel of liquid; BNGL, barrel of natural gas liquids; no., number; m, meter; AU, assessment unit; API, American Petroleum Institute; IHS, IHS Markit; AL, Alabama; FL, Florida; LA, Louisiana; MS, Mississippi; TX, Texas; \%, percent] 
USGS U.S. PETROLEUM RESOURCES ASSESSMENT

INPUT FORM FOR CONVENTIONAL ASSESSMENT UNITS (Version 7.0.2, 9 April 2015)

IDENTIFICATION INFORMATION

Assessment Geologist:

Region:

Province:

Total Petroleum System:

Assessment Unit:

Scenario:

Based on Data as of:

Notes from Assessor:
S.T. Paxton

North America

Gulf Coast Mesozoic

Upper Jurassic-Cretaceous-Tertiary Composite

Bossier Eastern Shelf Sandstone Gas and Oil

IHS (2016)

Coproducts and ancillary data for oil accumulations from Haynesville Eastern

Shelf 50490117 and gas accumulations from Haynesville Western Shelf 50490116

\section{CHARACTERISTICS OF ASSESSMENT UNIT}

Area of assessment unit:

Minimum assessed accumulation size:

No. of discovered accumulations exceeding minimum size:
Check One Number

Producing fields

Discoveries

Wells

Seismic

No seismic
246,632 square kilometers

0.5 MMBOE (grown)

Oil: 0 Gas: 0

Median size (grown) of discovered oil accumulations (MMBO):

1st 3rd

2nd 3rd

3rd 3rd

Median size (grown) of discovered gas accumulations (BCFG):

1 st 3rd

2nd 3rd

3rd 3rd

\section{ANALOGS USED IN ESTIMATING INPUT}

\section{Purpose}

1

2

3

4

西

Analog or Analog Set

$\overline{-10}$


Scenario Probability:

\section{Assessment-Unit Probabilities: $\quad$ (Adequacy for at least one undiscovered field of minimum size)}

Attribute

1. CHARGE: Adequate petroleum charge:

2. ROCKS: Adequate reservoirs, traps, and seals:

3. TIMING OF GEOLOGIC EVENTS: Favorable timing:

\section{UNDISCOVERED ACCUMULATIONS}

Number of Undiscovered Accumulations: How many undiscovered accumulations exist that are at least the minimum size?: (uncertainty of fixed but unknown values)

Total Accumulations:

minimum $(>0)$

median maximum

Oil/Gas Mix:

minimum

mode maximum number of oil accumulations / number of total accumulations number of oil accumulations / number of gas accumulations number of gas accumulations / number of oil accumulations

Oil Accumulations:

Gas Accumulations:

$\operatorname{minimum}_{\text {minimum }} \frac{1}{1}$

$\begin{array}{ll}\text { median } & 200 \\ \text { median } & \text { maximum } \\ \text { maximum }\end{array}$ 500 1000

Sizes of Undiscovered Accumulations: What are the sizes (grown) of the above accumulations?: (variations in the sizes of undiscovered accumulations)

Oil in Oil Accumulations (MMBO): Gas in Gas Accumulations (BCFG): minimum minimum

$\frac{0.5}{3}$

median

1.5

maximum maximum

\section{RATIOS FOR UNDISCOVERED ACCUMULATIONS, TO ASSESS COPRODUCTS}

(variations in the properties of undiscovered accumulations)

Oil Accumulations:

Gas/oil ratio (CFG/BO):

NGL/gas ratio (BNGL/MMCFG):

Gas Accumulations:

Liquids/gas ratio (BLIQ/MMCFG):

\begin{tabular}{c}
$\begin{array}{c}\text { minimum } \\
2\end{array}$ \\
\hline 32 \\
\hline
\end{tabular}

minimum

0.1

\begin{tabular}{c}
$\begin{array}{c}\text { median } \\
1250\end{array}$ \\
\hline 102 \\
\hline $\begin{array}{c}\text { median } \\
8\end{array}$ \\
\hline
\end{tabular}

maximum 5500 132

maximum 46 


\section{SELECTED ANCILLARY DATA FOR UNDISCOVERED ACCUMULATIONS}

(variations in the properties of undiscovered accumulations)

Oil Accumulations:

API gravity (degrees):

Viscosity (centipoise):

Sulfur content of oil (\%):

Depth $(\mathrm{m})$ of water (if applicable):

Drilling Depth $(m)$ :

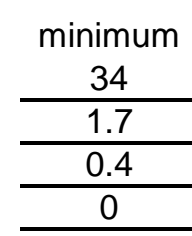

$$
\text { minimum }
$$

2000

\section{F75}

\begin{tabular}{c}
$\begin{array}{c}\text { median } \\
47\end{array}$ \\
\hline 2 \\
\hline 0.5 \\
\hline 5 \\
\hline
\end{tabular}

median

3700

F25

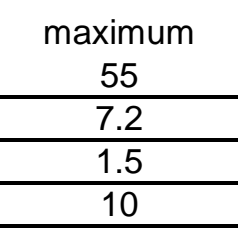

maximum 5500

Gas Accumulations:

Inert gas content (\%):

Carbon dioxide content (\%):

Hydrogen sulfide content (\%):

Depth (m) of water (if applicable):

Drilling Depth (m):

minimum

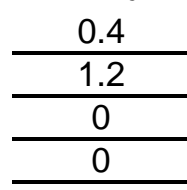

minimum

2000 median

\begin{tabular}{c}
0.7 \\
\hline 2.2 \\
\hline 0.06 \\
\hline 5 \\
\hline
\end{tabular}

F75

median

5000

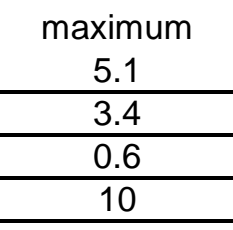

F25

10000 


\section{ALLOCATIONS OF POTENTIAL ADDITIONS TO RESERVES TO STATES Surface Allocations}

1. Alabama

Onshore: $\quad 8.95$ area \% of the $\mathrm{AU}$

Oil in Oil Accumulations:

8.95 volume $\%$ of the $\mathrm{AU}$

Gas in Gas Accumulations:

8.95 volume $\%$ of the $\mathrm{AU}$

Offshore: area $\%$ of the $\mathrm{AU}$

Oil in Oil Accumulations:

volume $\%$ of the $\mathrm{AU}$

Gas in Gas Accumulations: volume $\%$ of the $\mathrm{AU}$

2. Arkansas

Onshore: $\quad 4.75$ area $\%$ of the $\mathrm{AU}$

Oil in Oil Accumulations:

4.75 volume $\%$ of the $\mathrm{AU}$

Gas in Gas Accumulations:

4.75 volume $\%$ of the $\mathrm{AU}$

Offshore: area $\%$ of the $\mathrm{AU}$

Oil in Oil Accumulations:

volume $\%$ of the $\mathrm{AU}$

Gas in Gas Accumulations: volume $\%$ of the $\mathrm{AU}$

3. Florida

Onshore: $\quad 4.39$ area $\%$ of the $\mathrm{AU}$

Oil in Oil Accumulations:

4.39 volume $\%$ of the $\mathrm{AU}$

Gas in Gas Accumulations:

4.39 volume $\%$ of the $\mathrm{AU}$

Offshore: area $\%$ of the $\mathrm{AU}$

Oil in Oil Accumulations: volume $\%$ of the $\mathrm{AU}$ Gas in Gas Accumulations: volume $\%$ of the $A U$

4. Louisiana

Onshore: 499.26 area \% of the $\mathrm{AU}$

Oil in Oil Accumulations: 49.26 volume $\%$ of the $\mathrm{AU}$

Gas in Gas Accumulations:

49.26 volume $\%$ of the $\mathrm{AU}$

Offshore: area $\%$ of the $\mathrm{AU}$

Oil in Oil Accumulations:

volume $\%$ of the $\mathrm{AU}$

Gas in Gas Accumulations: volume $\%$ of the $\mathrm{AU}$ 


\section{ALLOCATIONS OF POTENTIAL ADDITIONS TO RESERVES TO STATES Surface Allocations}

5. Mississippi

Onshore: $\quad 26.25$ area $\%$ of the $\mathrm{AU}$

Oil in Oil Accumulations: 26.25 volume $\%$ of the $\mathrm{AU}$

Gas in Gas Accumulations:

26.25 volume $\%$ of the $\mathrm{AU}$

Offshore: area $\%$ of the $\mathrm{AU}$

Oil in Oil Accumulations: volume $\%$ of the $\mathrm{AU}$

Gas in Gas Accumulations: volume $\%$ of the $\mathrm{AU}$

6. Texas

Onshore: $\quad 6.42$ area $\%$ of the $\mathrm{AU}$

Oil in Oil Accumulations:

Gas in Gas Accumulations:

Offshore: area $\%$ of the $\mathrm{AU}$

Oil in Oil Accumulations:

Gas in Gas Accumulations:
6.42 volume $\%$ of the AU

6.42 volume $\%$ of the $\mathrm{AU}$

volume $\%$ of the $\mathrm{AU}$ volume $\%$ of the $\mathrm{AU}$

7.

Onshore: area $\%$ of the $A U$

Oil in Oil Accumulations: volume $\%$ of the $\mathrm{AU}$ Gas in Gas Accumulations: volume $\%$ of the $\mathrm{AU}$

Offshore: area $\%$ of the $\mathrm{AU}$

Oil in Oil Accumulations: volume $\%$ of the $\mathrm{AU}$ Gas in Gas Accumulations: volume $\%$ of the $\mathrm{AU}$

8.

Onshore: area $\%$ of the $\mathrm{AU}$

Oil in Oil Accumulations: volume $\%$ of the $\mathrm{AU}$ Gas in Gas Accumulations: volume $\%$ of the $\mathrm{AU}$

Offshore: area \% of the $\mathrm{AU}$

Oil in Oil Accumulations: Gas in Gas Accumulations: volume $\%$ of the $\mathrm{AU}$ 


\section{ALLOCATIONS OF POTENTIAL ADDITIONS TO RESERVES TO STATES Surface Allocations}

9.

Onshore: area $\%$ of the $\mathrm{AU}$

Oil in Oil Accumulations: volume $\%$ of the $\mathrm{AU}$

Gas in Gas Accumulations: volume $\%$ of the $\mathrm{AU}$

Offshore: area \% of the AU

Oil in Oil Accumulations: volume $\%$ of the $\mathrm{AU}$

Gas in Gas Accumulations: volume $\%$ of the $\mathrm{AU}$

10.

Onshore: area $\%$ of the $\mathrm{AU}$

Oil in Oil Accumulations: volume $\%$ of the $\mathrm{AU}$

Gas in Gas Accumulations: volume $\%$ of the $\mathrm{AU}$

Offshore: area $\%$ of the $\mathrm{AU}$

Oil in Oil Accumulations: volume $\%$ of the $\mathrm{AU}$

Gas in Gas Accumulations: volume $\%$ of the $\mathrm{AU}$

11.

Onshore: area $\%$ of the $\mathrm{AU}$

Oil in Oil Accumulations: volume $\%$ of the $\mathrm{AU}$ Gas in Gas Accumulations: volume $\%$ of the $\mathrm{AU}$

Offshore: area $\%$ of the $\mathrm{AU}$

Oil in Oil Accumulations: volume $\%$ of the $\mathrm{AU}$ Gas in Gas Accumulations: volume $\%$ of the $A U$

12.

Onshore: area \% of the $\mathrm{AU}$

Oil in Oil Accumulations: volume $\%$ of the $\mathrm{AU}$ Gas in Gas Accumulations: volume $\%$ of the $\mathrm{AU}$

Offshore: area \% of the $\mathrm{AU}$

Oil in Oil Accumulations: Gas in Gas Accumulations: 


\section{ALLOCATIONS OF POTENTIAL ADDITIONS TO RESERVES TO PROVINCES Surface Allocations}

1.

Province Number: 5049 Name: Gulf Coast Mesozoic

Onshore: 100.00 area $\%$ of the $\mathrm{AU}$

Oil in Oil Accumulations: $\quad 100.00$ volume $\%$ of the $\mathrm{AU}$

Gas in Gas Accumulations: $\quad 100.00$ volume $\%$ of the $A U$

Offshore: area \% of the AU

Oil in Oil Accumulations: volume $\%$ of the $\mathrm{AU}$

Gas in Gas Accumulations: volume $\%$ of the $\mathrm{AU}$

2. Province Number:

Name:

Onshore: area \% of the AU

Oil in Oil Accumulations: volume $\%$ of the $\mathrm{AU}$

Gas in Gas Accumulations: volume $\%$ of the $\mathrm{AU}$

Offshore: area $\%$ of the $\mathrm{AU}$

Oil in Oil Accumulations: volume $\%$ of the $\mathrm{AU}$

Gas in Gas Accumulations: volume $\%$ of the $\mathrm{AU}$

3. Province Number:

Name:

Onshore: area $\%$ of the $\mathrm{AU}$

Oil in Oil Accumulations: volume $\%$ of the $\mathrm{AU}$ Gas in Gas Accumulations: volume $\%$ of the $\mathrm{AU}$

Offshore: area $\%$ of the $\mathrm{AU}$

Oil in Oil Accumulations: volume $\%$ of the $\mathrm{AU}$ Gas in Gas Accumulations: volume $\%$ of the $\mathrm{AU}$

4. Province Number:

Name:

Onshore: area $\%$ of the $\mathrm{AU}$

Oil in Oil Accumulations: volume $\%$ of the $\mathrm{AU}$ Gas in Gas Accumulations: volume $\%$ of the $\mathrm{AU}$

Offshore: area $\%$ of the $\mathrm{AU}$

Oil in Oil Accumulations: Gas in Gas Accumulations: 


\section{ALLOCATIONS OF POTENTIAL ADDITIONS TO RESERVES TO PROVINCES Surface Allocations}

5.

Province Number:

Name:

Onshore: area $\%$ of the $\mathrm{AU}$

Oil in Oil Accumulations: volume $\%$ of the $\mathrm{AU}$

Gas in Gas Accumulations: volume $\%$ of the $\mathrm{AU}$

Offshore: area \% of the $\mathrm{AU}$

Oil in Oil Accumulations: volume $\%$ of the $\mathrm{AU}$

Gas in Gas Accumulations: volume $\%$ of the $\mathrm{AU}$

6. Province Number:

Name:

Onshore: area $\%$ of the $\mathrm{AU}$

Oil in Oil Accumulations: volume $\%$ of the $\mathrm{AU}$

Gas in Gas Accumulations: volume $\%$ of the $\mathrm{AU}$

Offshore: area $\%$ of the $\mathrm{AU}$

Oil in Oil Accumulations: volume $\%$ of the $\mathrm{AU}$

Gas in Gas Accumulations: volume $\%$ of the $A U$

7. Province Number:

Name:

Onshore: area $\%$ of the $\mathrm{AU}$

Oil in Oil Accumulations: volume $\%$ of the $\mathrm{AU}$ Gas in Gas Accumulations: volume $\%$ of the $\mathrm{AU}$

Offshore: area $\%$ of the $\mathrm{AU}$

Oil in Oil Accumulations: volume $\%$ of the $\mathrm{AU}$ Gas in Gas Accumulations: volume $\%$ of the $\mathrm{AU}$

8. Province Number:

Name:

Onshore: area $\%$ of the $\mathrm{AU}$

Oil in Oil Accumulations: volume $\%$ of the $\mathrm{AU}$ Gas in Gas Accumulations: volume $\%$ of the $\mathrm{AU}$

Offshore: area \% of the $\mathrm{AU}$

Oil in Oil Accumulations: Gas in Gas Accumulations: 


\section{ALLOCATIONS OF POTENTIAL ADDITIONS TO RESERVES TO LAND ENTITIES Surface Allocations}

1. Federal Lands represents 5.25 area $\%$ of the $\mathrm{AU}$

Oil in Oil Accumulations: Gas in Gas Accumulations:
5.25 volume $\%$ of the $\mathrm{AU}$ 5.25 volume $\%$ of the $\mathrm{AU}$ represents $\quad 0.89$ area $\%$ of the $A U$

2. Private Lands

Oil in Oil Accumulations: 0.89 volume $\%$ of the $\mathrm{AU}$

Gas in Gas Accumulations: represents 0.01 area $\%$ of the $\mathrm{AU}$

3. Tribal Lands

Oil in Oil Accumulations: 0.01 volume $\%$ of the $\mathrm{AU}$ 0.01 volume $\%$ of the $\mathrm{AU}$

Gas in Gas Accumulations: represents 82.64 area $\%$ of the $\mathrm{AU}$

Oil in Oil Accumulations:

Gas in Gas Accumulations:

82.64 volume $\%$ of the $\mathrm{AU}$

82.64 volume $\%$ of the $\mathrm{AU}$

represents $\quad 0.20$ area $\%$ of the $A U$

Oil in Oil Accumulations:

Gas in Gas Accumulations:

0.20 volume $\%$ of the $\mathrm{AU}$

0.20 volume $\%$ of the $\mathrm{AU}$

represents 0.02 area $\%$ of the $\mathrm{AU}$

Oil in Oil Accumulations:

Gas in Gas Accumulations:

$\begin{array}{ll}0.02 & \text { volume } \% \text { of the } \mathrm{AU} \\ 0.02 & \text { volume } \% \text { of the } \mathrm{AU}\end{array}$

represents 1.75 area $\%$ of the $\mathrm{AU}$

Oil in Oil Accumulations:

Gas in Gas Accumulations:

1.75 volume $\%$ of the $\mathrm{AU}$

1.75 volume $\%$ of the $\mathrm{AU}$

represents 0.10 area $\%$ of the $\mathrm{AU}$

8. MS State Lands

0.10 volume $\%$ of the $\mathrm{AU}$

0.10 volume $\%$ of the $\mathrm{AU}$
Oil in Oil Accumulations:

Gas in Gas Accumulations:

0.10 volume $\%$ of the AU




\section{ALLOCATIONS OF POTENTIAL ADDITIONS TO RESERVES TO LAND ENTITIES Surface Allocations}

9. TX State Lands represents 0.08 area $\%$ of the $\mathrm{AU}$
Oil in Oil Accumulations: Gas in Gas Accumulations: volume $\%$ of the $\mathrm{AU}$ volume $\%$ of the $\mathrm{AU}$
10. AL Offshore represents $\quad 0.80 \quad$ area $\%$ of the $\mathrm{AU}$
Oil in Oil Accumulations:

Gas in Gas Accumulations:

11. FL Offshore represents volume $\%$ of the $\mathrm{AU}$ 0.80 volume $\%$ of the $\mathrm{AU}$

Oil in Oil Accumulations:

Gas in Gas Accumulations:

12. LA Offshore

Oil in Oil Accumulations:

Gas in Gas Accumulations:

13. MS Offshore

Oil in Oil Accumulations:

Gas in Gas Accumulations:

14. TX Offshore

Oil in Oil Accumulations:

Gas in Gas Accumulations:

15. represents 0.24 volume $\%$ of the $\mathrm{AU}$ 0.24 volume $\%$ of the $\mathrm{AU}$

5.95 volume $\%$ of the $\mathrm{AU}$ 5.95 volume $\%$ of the $\mathrm{AU}$ represents 0.81 area $\%$ of the $A U$ 0.81 volume $\%$ of the $\mathrm{AU}$ 0.81 volume $\%$ of the $\mathrm{AU}$ represents 0.24 area $\%$ of the $\mathrm{AU}$ $\frac{1.26}{1.26}$ volume $\%$ of the $\mathrm{AU}$ represents 5.95 area $\%$ of the $\mathrm{AU}$ 0.08 


\section{ALLOCATIONS OF POTENTIAL ADDITIONS TO RESERVES TO FEDERAL LAND SUBDIVISIONS Surface Allocations}

1. Bureau of Land Management (BLM) represents 0.00 area $\%$ of the $\mathrm{AU}$

Oil in Oil Accumulations: Gas in Gas Accumulations:

$\begin{array}{ll}0.00 & \text { volume } \% \text { of the } \mathrm{AU} \\ 0.00 & \text { volume } \% \text { of the } \mathrm{AU}\end{array}$

2. BLM Wilderness Areas (BLMW) represents area \% of the $\mathrm{AU}$

Oil in Oil Accumulations: volume $\%$ of the $\mathrm{AU}$

Gas in Gas Accumulations: volume $\%$ of the $\mathrm{AU}$

3. BLM Roadless Areas (BLMR) represents area $\%$ of the $A U$

Oil in Oil Accumulations: volume $\%$ of the $\mathrm{AU}$

Gas in Gas Accumulations: volume $\%$ of the $\mathrm{AU}$

4. National Park Service (NPS) represents 0.04 area $\%$ of the $A U$

Oil in Oil Accumulations: 0.04 volume $\%$ of the $\mathrm{AU}$ Gas in Gas Accumulations: 0.04 volume $\%$ of the $\mathrm{AU}$

5. NPS Wilderness Areas (NPSW) represents area $\%$ of the $\mathrm{AU}$

Oil in Oil Accumulations: volume $\%$ of the $\mathrm{AU}$ Gas in Gas Accumulations: volume $\%$ of the $\mathrm{AU}$

6. NPS Protected Withdrawals (NPSP) represents area $\%$ of the $A U$

Oil in Oil Accumulations: volume $\%$ of the $\mathrm{AU}$ Gas in Gas Accumulations: volume $\%$ of the $\mathrm{AU}$

7. US Forest Service (FS) represents 2.49 area $\%$ of the AU

Oil in Oil Accumulations: Gas in Gas Accumulations:

8. USFS Wilderness Areas (FSW) represents area $\%$ of the $\mathrm{AU}$

Oil in Oil Accumulations: Gas in Gas Accumulations:
2.49 volume $\%$ of the $\mathrm{AU}$

2.49 volume $\%$ of the $\mathrm{AU}$

volume $\%$ of the $\mathrm{AU}$ volume $\%$ of the $\mathrm{AU}$ 


\section{ALLOCATIONS OF POTENTIAL ADDITIONS TO RESERVES TO FEDERAL LAND SUBDIVISIONS Surface Allocations}

9. USFS Roadless Areas (FSR) represents area $\%$ of the $\mathrm{AU}$

Oil in Oil Accumulations: volume $\%$ of the $\mathrm{AU}$

Gas in Gas Accumulations: volume $\%$ of the $\mathrm{AU}$

10. USFS Protected Withdrawals (FSP) represents area $\%$ of the $\mathrm{AU}$

Oil in Oil Accumulations: volume $\%$ of the $\mathrm{AU}$ Gas in Gas Accumulations: volume $\%$ of the $\mathrm{AU}$

11. US Fish and Wildlife Service (FWS) represents 1.16 area $\%$ of the $\mathrm{AU}$

Oil in Oil Accumulations:

Gas in Gas Accumulations:

12. USFWS Wilderness Areas (FWSW)

Oil in Oil Accumulations:

Gas in Gas Accumulations:

13. USFWS Protected Withdrawals (FWSP)

Oil in Oil Accumulations:

Gas in Gas Accumulations:

14. Wilderness Study Areas (WS)

Oil in Oil Accumulations:

Gas in Gas Accumulations:

15. Department of Energy (DOE)

Oil in Oil Accumulations: Gas in Gas Accumulations:

16. Department of Defense (DOD)

Oil in Oil Accumulations:

Gas in Gas Accumulations: represents

area $\%$ of the $\mathrm{AU}$

volume $\%$ of the $\mathrm{AU}$ volume $\%$ of the $\mathrm{AU}$

represents area $\%$ of the $\mathrm{AU}$

volume $\%$ of the $\mathrm{AU}$ volume $\%$ of the $\mathrm{AU}$

represents area \% of the $\mathrm{AU}$ volume $\%$ of the $\mathrm{AU}$ volume $\%$ of the $\mathrm{AU}$

represents area $\%$ of the $\mathrm{AU}$ volume $\%$ of the $\mathrm{AU}$ volume $\%$ of the $\mathrm{AU}$ represents 1.56 area $\%$ of the $\mathrm{AU}$ 1.56 volume $\%$ of the $\mathrm{AU}$ 1.56 volume $\%$ of the $\mathrm{AU}$ 


\section{ALLOCATIONS OF POTENTIAL ADDITIONS TO RESERVES TO FEDERAL LAND SUBDIVISIONS Surface Allocations}

17. Bureau of Reclamation (BOR) represents area $\%$ of the $\mathrm{AU}$

Oil in Oil Accumulations: volume $\%$ of the $\mathrm{AU}$

Gas in Gas Accumulations: volume $\%$ of the $A U$

18. Tennessee Valley Authority (TVA) represents area $\%$ of the $\mathrm{AU}$

Oil in Oil Accumulations: volume $\%$ of the $\mathrm{AU}$

Gas in Gas Accumulations: volume $\%$ of the $\mathrm{AU}$

19. Other Federal represents area $\%$ of the $\mathrm{AU}$

Oil in Oil Accumulations:

Gas in Gas Accumulations:

20.

Oil in Oil Accumulations:

Gas in Gas Accumulations: volume $\%$ of the $\mathrm{AU}$ volume $\%$ of the $\mathrm{AU}$

represents area $\%$ of the $\mathrm{AU}$

volume $\%$ of the $\mathrm{AU}$ volume $\%$ of the $\mathrm{AU}$ 


\section{ALLOCATIONS OF POTENTIAL ADDITIONS TO RESERVES TO ECOSYSTEMS Surface Allocations}

1. Coastal Plains and Flatwoods, Lower (CPFL) represents 20.47 area $\%$ of the $\mathrm{AU}$

Oil in Oil Accumulations:

Gas in Gas Accumulations:
20.47 volume $\%$ of the $\mathrm{AU}$

20.47 volume $\%$ of the $\mathrm{AU}$

represents 8.13 area $\%$ of the $\mathrm{AU}$

8.13 volume $\%$ of the $\mathrm{AU}$

8.13 volume $\%$ of the $\mathrm{AU}$

Oil in Oil Accumulations:
Gas in Gas Accumulations: represents 14.36 area $\%$ of the $\mathrm{AU}$

3. Coastal Plains, Middle (CPMD)

14.36 volume $\%$ of the $\mathrm{AU}$

Oil in Oil Accumulations:

14.36 volume $\%$ of the $\mathrm{AU}$

Gas in Gas Accumulations:

represents 0.41 area $\%$ of the $\mathrm{AU}$

4. Eastern Gulf Prairies and Marshes (EGPM)

0.41 volume $\%$ of the $\mathrm{AU}$

Oil in Oil Accumulations:

0.41 volume $\%$ of the $\mathrm{AU}$

Gas in Gas Accumulations:

represents 1.12 area $\%$ of the $\mathrm{AU}$

5. Florida Coastal Lowlands (Western) (FCLW)

1.12 volume $\%$ of the $\mathrm{AU}$

Oil in Oil Accumulations:

1.12 volume $\%$ of the $\mathrm{AU}$

Gas in Gas Accumulations:

represents 14.91 area $\%$ of the $\mathrm{AU}$

6. Louisiana Coast Prairies and Marshes (LCPM)

14.91 volume $\%$ of the $\mathrm{AU}$

Oil in Oil Accumulations:

14.91 volume $\%$ of the $\mathrm{AU}$

7. Mid Coastal Plains, Western (MCPW)

represents 13.82 area $\%$ of the $A U$

Oil in Oil Accumulations:

13.82 volume $\%$ of the $\mathrm{AU}$

Gas in Gas Accumulations:

13.82 volume $\%$ of the $\mathrm{AU}$

8. Mississippi Alluvial Basin (MABA) represents 17.72 area \% of the $\mathrm{AU}$

Oil in Oil Accumulations:

17.72 volume $\%$ of the $\mathrm{AU}$

Gas in Gas Accumulations:

17.72 volume $\%$ of the $\mathrm{AU}$

Ecosystem allocations do not include offshore areas, hence, sum total $<100 \%$ 


\section{ALLOCATIONS OF POTENTIAL ADDITIONS TO RESERVES TO ECOSYSTEMS Surface Allocations}

9. represents area $\%$ of the $\mathrm{AU}$

Oil in Oil Accumulations: volume $\%$ of the $\mathrm{AU}$

Gas in Gas Accumulations: volume $\%$ of the $\mathrm{AU}$

10. represents area \% of the $\mathrm{AU}$

Oil in Oil Accumulations: volume $\%$ of the $\mathrm{AU}$

Gas in Gas Accumulations: volume $\%$ of the $\mathrm{AU}$

11. represents area $\%$ of the $\mathrm{AU}$

Oil in Oil Accumulations:

Gas in Gas Accumulations:

Oil in Oil Accumulations:

Gas in Gas Accumulations: represents area $\%$ of the $\mathrm{AU}$

volume $\%$ of the $\mathrm{AU}$ volume $\%$ of the $\mathrm{AU}$

volume $\%$ of the $\mathrm{AU}$ volume $\%$ of the $\mathrm{AU}$

Ecosystem allocations do not include offshore areas, hence the sum total $<100 \%$ 
Table 2. Input parameters for the Bossier Western Shelf Sandstone Gas Assessment Unit (50490119), Onshore U.S. Gulf Coast Province.

[Field-scale data from Nehring (2016), and well production data from IHS Markit ${ }^{\mathrm{TM}}$ (2016). BCFG, billion cubic feet of gas; MMCFG, million cubic feet of gas; CFG, cubic feet of gas; MMBO, million barrels of oil; MMBOE, million barrels of oil equivalent; BO, barrel of oil; BLIQ, barrel of liquid; BNGL, barrel of natural gas liquids; no., number; m, meter; AU, assessment unit; API, American Petroleum Institute; NRG, Nehring database; IHS, IHS Markit; TX, Texas; \%, percent] 
USGS U.S. PETROLEUM RESOURCES ASSESSMENT

INPUT FORM FOR CONVENTIONAL ASSESSMENT UNITS (Version 7.0.2, 9 April 2015)

IDENTIFICATION INFORMATION

Assessment Geologist:

Region:

Province:

S.T. Paxton

North America

Gulf Coast Mesozoic

Total Petroleum System:

Assessment Unit:

Upper Jurassic-Cretaceous-Tertiary Composite

Bossier Western Shelf Sandstone Gas

Scenario:

Based on Data as of:

Notes from Assessor:

NRG (2016, data current through 2014), IHS (2016)

Date: $\quad 20-O c t-16$

Number: 5

Number: 5049

Number: 504901

Number: 50490119 Number:

CHARACTERISTICS OF ASSESSMENT UNIT

Area of assessment unit:

Minimum assessed accumulation size:

No. of discovered accumulations exceeding minimum size:

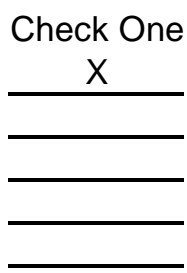

66,411 square kilometers

0.5 MMBOE (grown)

Oil: 0 Gas: 22

Median size (grown) of discovered oil accumulations (MMBO):

1st 3rd

Median size (grown) of discovered gas accumulations (BCFG):

1st 3rd 25.42 2nd 3rd

2nd 3rd 24.23 3rd 3rd

3rd 3rd

9.01

ANALOGS USED IN ESTIMATING INPUT

Analog or Analog Set

1

2

Purpose

(1)

3

4 
Scenario Probability:

\section{Assessment-Unit Probabilities: $\quad$ (Adequacy for at least one undiscovered field of minimum size)}

Attribute

1. CHARGE: Adequate petroleum charge:

2. ROCKS: Adequate reservoirs, traps, and seals:

3. TIMING OF GEOLOGIC EVENTS: Favorable timing:

\section{UNDISCOVERED ACCUMULATIONS}

Number of Undiscovered Accumulations: How many undiscovered accumulations exist that are at least the minimum size?: (uncertainty of fixed but unknown values)

Total Accumulations:

minimum $(>0)$

median maximum

Oil/Gas Mix:

minimum

mode maximum number of oil accumulations / number of total accumulations number of oil accumulations / number of gas accumulations number of gas accumulations / number of oil accumulations

Oil Accumulations:

Gas Accumulations:

$\operatorname{minimum}_{\text {minimum }} \frac{0}{1}$

median 0 maximum median $80 \quad$ maximum

Sizes of Undiscovered Accumulations: What are the sizes (grown) of the above accumulations?: (variations in the sizes of undiscovered accumulations)

Oil in Oil Accumulations (MMBO): Gas in Gas Accumulations (BCFG): minimum minimum median
median

6
maximum maximum

\section{RATIOS FOR UNDISCOVERED ACCUMULATIONS, TO ASSESS COPRODUCTS}

(variations in the properties of undiscovered accumulations)

Oil Accumulations:

Gas/oil ratio (CFG/BO):

NGL/gas ratio (BNGL/MMCFG):

Gas Accumulations:

Liquids/gas ratio (BLIQ/MMCFG): minimum

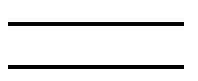

minimum

0.1

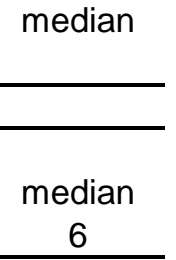

maximum

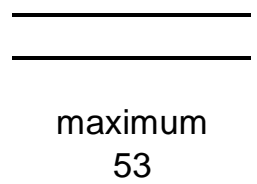




\section{SELECTED ANCILLARY DATA FOR UNDISCOVERED ACCUMULATIONS}

(variations in the properties of undiscovered accumulations)

Oil Accumulations:

API gravity (degrees):

Viscosity (centipoise):

Sulfur content of oil (\%):

Depth $(\mathrm{m})$ of water (if applicable):

Drilling Depth (m):

Gas Accumulations:

Inert gas content (\%):

Carbon dioxide content (\%):

Hydrogen sulfide content (\%):

Depth (m) of water (if applicable):

Drilling Depth (m):

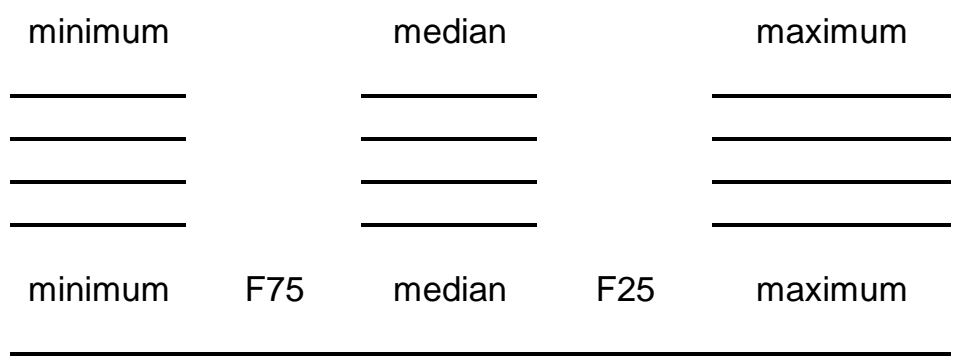

minimum

\begin{tabular}{c}
0.1 \\
\hline 1.3 \\
\hline 0 \\
\hline
\end{tabular}

minimum

2700

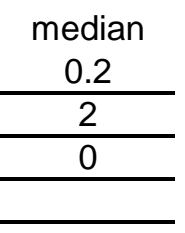

F75

median

3500

\begin{tabular}{c}
$\begin{array}{c}\text { maximum } \\
0.3\end{array}$ \\
\hline 2.6 \\
\hline 0 \\
\hline \\
\hline \\
maximum \\
6000 \\
\hline
\end{tabular}




\section{ALLOCATIONS OF POTENTIAL ADDITIONS TO RESERVES TO STATES Surface Allocations}

1. Texas

Onshore: 100.00 area \% of the $\mathrm{AU}$

Oil in Oil Accumulations: volume $\%$ of the $\mathrm{AU}$

Gas in Gas Accumulations: volume $\%$ of the $\mathrm{AU}$

Offshore: area $\%$ of the $\mathrm{AU}$

Oil in Oil Accumulations: volume $\%$ of the $\mathrm{AU}$

Gas in Gas Accumulations: volume $\%$ of the $\mathrm{AU}$

2.

Onshore: area $\%$ of the $\mathrm{AU}$

Oil in Oil Accumulations: volume $\%$ of the $\mathrm{AU}$

Gas in Gas Accumulations: volume $\%$ of the $\mathrm{AU}$

Offshore: area $\%$ of the $\mathrm{AU}$

Oil in Oil Accumulations: volume $\%$ of the $\mathrm{AU}$

Gas in Gas Accumulations: volume $\%$ of the $\mathrm{AU}$

3.

Onshore: area $\%$ of the $\mathrm{AU}$

Oil in Oil Accumulations: volume $\%$ of the $\mathrm{AU}$ Gas in Gas Accumulations: volume $\%$ of the $\mathrm{AU}$

Offshore: area $\%$ of the $\mathrm{AU}$

Oil in Oil Accumulations: volume $\%$ of the $\mathrm{AU}$ Gas in Gas Accumulations: volume $\%$ of the $\mathrm{AU}$

4.

Onshore: area $\%$ of the $\mathrm{AU}$

Oil in Oil Accumulations: volume $\%$ of the $\mathrm{AU}$ Gas in Gas Accumulations: volume $\%$ of the $\mathrm{AU}$

Offshore: area $\%$ of the $\mathrm{AU}$

Oil in Oil Accumulations: Gas in Gas Accumulations: volume $\%$ of the $\mathrm{AU}$ 


\section{ALLOCATIONS OF POTENTIAL ADDITIONS TO RESERVES TO STATES Surface Allocations}

5.

Onshore: area $\%$ of the $\mathrm{AU}$

Oil in Oil Accumulations: volume $\%$ of the $\mathrm{AU}$

Gas in Gas Accumulations: volume $\%$ of the $\mathrm{AU}$

Offshore: area \% of the AU

Oil in Oil Accumulations: volume $\%$ of the $\mathrm{AU}$

Gas in Gas Accumulations: volume $\%$ of the $\mathrm{AU}$

6.

Onshore: area $\%$ of the $\mathrm{AU}$

Oil in Oil Accumulations: volume $\%$ of the $\mathrm{AU}$

Gas in Gas Accumulations: volume $\%$ of the $\mathrm{AU}$

Offshore: area $\%$ of the $\mathrm{AU}$

Oil in Oil Accumulations: volume $\%$ of the $\mathrm{AU}$

Gas in Gas Accumulations: volume $\%$ of the $\mathrm{AU}$

7.

Onshore: area $\%$ of the $\mathrm{AU}$

Oil in Oil Accumulations: volume $\%$ of the $\mathrm{AU}$ Gas in Gas Accumulations: volume $\%$ of the $\mathrm{AU}$

Offshore: area $\%$ of the $\mathrm{AU}$

Oil in Oil Accumulations: volume $\%$ of the $\mathrm{AU}$ Gas in Gas Accumulations: volume $\%$ of the $A U$

8.

Onshore: area \% of the $\mathrm{AU}$

Oil in Oil Accumulations: volume $\%$ of the $\mathrm{AU}$ Gas in Gas Accumulations: volume $\%$ of the $\mathrm{AU}$

Offshore: area \% of the $\mathrm{AU}$

Oil in Oil Accumulations: Gas in Gas Accumulations: 


\section{ALLOCATIONS OF POTENTIAL ADDITIONS TO RESERVES TO STATES Surface Allocations}

9.

Onshore: area $\%$ of the $\mathrm{AU}$

Oil in Oil Accumulations: volume $\%$ of the $\mathrm{AU}$

Gas in Gas Accumulations: volume $\%$ of the $\mathrm{AU}$

Offshore: area \% of the AU

Oil in Oil Accumulations: volume $\%$ of the $\mathrm{AU}$

Gas in Gas Accumulations: volume $\%$ of the $\mathrm{AU}$

10.

Onshore: area $\%$ of the $\mathrm{AU}$

Oil in Oil Accumulations: volume $\%$ of the $\mathrm{AU}$

Gas in Gas Accumulations: volume $\%$ of the $\mathrm{AU}$

Offshore: area $\%$ of the $\mathrm{AU}$

Oil in Oil Accumulations: volume $\%$ of the $\mathrm{AU}$

Gas in Gas Accumulations: volume $\%$ of the $\mathrm{AU}$

11.

Onshore: area $\%$ of the $\mathrm{AU}$

Oil in Oil Accumulations: volume $\%$ of the $\mathrm{AU}$ Gas in Gas Accumulations: volume $\%$ of the $\mathrm{AU}$

Offshore: area $\%$ of the $\mathrm{AU}$

Oil in Oil Accumulations: volume $\%$ of the $\mathrm{AU}$ Gas in Gas Accumulations: volume $\%$ of the $\mathrm{AU}$

12.

Onshore: area \% of the $\mathrm{AU}$

Oil in Oil Accumulations: volume $\%$ of the $\mathrm{AU}$ Gas in Gas Accumulations: volume $\%$ of the $\mathrm{AU}$

Offshore: area \% of the $\mathrm{AU}$

Oil in Oil Accumulations: Gas in Gas Accumulations: 


\section{ALLOCATIONS OF POTENTIAL ADDITIONS TO RESERVES TO PROVINCES Surface Allocations}

1.

Province Number: 5049 Name: Gulf Coast Mesozoic

Onshore: 100.00 area $\%$ of the $\mathrm{AU}$

Oil in Oil Accumulations:

volume $\%$ of the $\mathrm{AU}$

Gas in Gas Accumulations: volume $\%$ of the $\mathrm{AU}$

Offshore: area \% of the $\mathrm{AU}$

Oil in Oil Accumulations: volume $\%$ of the $\mathrm{AU}$

Gas in Gas Accumulations: volume $\%$ of the $\mathrm{AU}$

2. Province Number:

Name:

Onshore: area $\%$ of the $\mathrm{AU}$

Oil in Oil Accumulations: volume $\%$ of the $\mathrm{AU}$

Gas in Gas Accumulations: volume $\%$ of the $\mathrm{AU}$

Offshore: area $\%$ of the $\mathrm{AU}$

Oil in Oil Accumulations: volume $\%$ of the $\mathrm{AU}$

Gas in Gas Accumulations: volume $\%$ of the $\mathrm{AU}$

3. Province Number:

Name:

Onshore: area $\%$ of the $\mathrm{AU}$

Oil in Oil Accumulations: volume $\%$ of the $\mathrm{AU}$ Gas in Gas Accumulations: volume $\%$ of the $\mathrm{AU}$

Offshore: area $\%$ of the $\mathrm{AU}$

Oil in Oil Accumulations: volume $\%$ of the $\mathrm{AU}$ Gas in Gas Accumulations: volume $\%$ of the $\mathrm{AU}$

4. Province Number:

Name:

Onshore: area \% of the $\mathrm{AU}$

Oil in Oil Accumulations: Gas in Gas Accumulations: volume $\%$ of the $\mathrm{AU}$

Offshore: area $\%$ of the $\mathrm{AU}$

Oil in Oil Accumulations: Gas in Gas Accumulations: 


\section{ALLOCATIONS OF POTENTIAL ADDITIONS TO RESERVES TO PROVINCES Surface Allocations}

5.

Province Number:

Name:

Onshore: area $\%$ of the $\mathrm{AU}$

Oil in Oil Accumulations: volume $\%$ of the $\mathrm{AU}$

Gas in Gas Accumulations: volume $\%$ of the $\mathrm{AU}$

Offshore: area \% of the $\mathrm{AU}$

Oil in Oil Accumulations: volume $\%$ of the $\mathrm{AU}$

Gas in Gas Accumulations: volume $\%$ of the $\mathrm{AU}$

6. Province Number:

Name:

Onshore: area $\%$ of the $\mathrm{AU}$

Oil in Oil Accumulations: volume $\%$ of the $\mathrm{AU}$

Gas in Gas Accumulations: volume $\%$ of the $\mathrm{AU}$

Offshore: area $\%$ of the $\mathrm{AU}$

Oil in Oil Accumulations: volume $\%$ of the $\mathrm{AU}$

Gas in Gas Accumulations: volume $\%$ of the $A U$

7. Province Number:

Name:

Onshore: area $\%$ of the $\mathrm{AU}$

Oil in Oil Accumulations: volume $\%$ of the $\mathrm{AU}$ Gas in Gas Accumulations: volume $\%$ of the $\mathrm{AU}$

Offshore: area $\%$ of the $\mathrm{AU}$

Oil in Oil Accumulations: volume $\%$ of the $\mathrm{AU}$ Gas in Gas Accumulations: volume $\%$ of the $\mathrm{AU}$

8. Province Number:

Name:

Onshore: area $\%$ of the $\mathrm{AU}$

Oil in Oil Accumulations: volume $\%$ of the $\mathrm{AU}$ Gas in Gas Accumulations: volume $\%$ of the $\mathrm{AU}$

Offshore: area \% of the $\mathrm{AU}$

Oil in Oil Accumulations: Gas in Gas Accumulations: 


\section{ALLOCATIONS OF POTENTIAL ADDITIONS TO RESERVES TO LAND ENTITIES Surface Allocations}

1. Federal Lands represents 0.81 area $\%$ of the $\mathrm{AU}$

Oil in Oil Accumulations: Gas in Gas Accumulations: volume $\%$ of the $\mathrm{AU}$ volume $\%$ of the $\mathrm{AU}$

2. Private Lands represents 0.10 area $\%$ of the $\mathrm{AU}$

Oil in Oil Accumulations:

Gas in Gas Accumulations:

3. Tribal Lands represents volume $\%$ of the $\mathrm{AU}$ volume $\%$ of the $\mathrm{AU}$
Oil in Oil Accumulations:

Gas in Gas Accumulations:

4. Other Lands

Oil in Oil Accumulations:

Gas in Gas Accumulations:

5. TX State Lands

Oil in Oil Accumulations:

Gas in Gas Accumulations:

6.

Oil in Oil Accumulations:

Gas in Gas Accumulations:

7.

Oil in Oil Accumulations:

Gas in Gas Accumulations:

8.

Oil in Oil Accumulations:

Gas in Gas Accumulations: represents 98.74 area $\%$ of the $\mathrm{AU}$

volume $\%$ of the $\mathrm{AU}$

98.74 volume $\%$ of the $\mathrm{AU}$

represents 0.35 area $\%$ of the $\mathrm{AU}$

volume $\%$ of the $\mathrm{AU}$

0.35 volume $\%$ of the $\mathrm{AU}$

represents

area $\%$ of the $\mathrm{AU}$

volume $\%$ of the $\mathrm{AU}$ volume $\%$ of the $\mathrm{AU}$

represents area $\%$ of the $\mathrm{AU}$

volume $\%$ of the $\mathrm{AU}$ volume $\%$ of the $\mathrm{AU}$

represents area $\%$ of the $\mathrm{AU}$

volume $\%$ of the $\mathrm{AU}$ volume $\%$ of the $\mathrm{AU}$ 


\section{ALLOCATIONS OF POTENTIAL ADDITIONS TO RESERVES TO LAND ENTITIES Surface Allocations}

9.

Oil in Oil Accumulations:

Gas in Gas Accumulations:

10.

11.

Oil in Oil Accumulations:

Gas in Gas Accumulations:

12.

Oil in Oil Accumulations:

Gas in Gas Accumulations:

13.

Oil in Oil Accumulations:

Gas in Gas Accumulations:

14.

Oil in Oil Accumulations:

Gas in Gas Accumulations:

15.

Oil in Oil Accumulations:

Gas in Gas Accumulations: represents

area $\%$ of the $\mathrm{AU}$

volume $\%$ of the $\mathrm{AU}$ volume $\%$ of the $\mathrm{AU}$

represents

area $\%$ of the $\mathrm{AU}$

volume $\%$ of the $\mathrm{AU}$

volume $\%$ of the $\mathrm{AU}$

represents area $\%$ of the $A U$

volume $\%$ of the $\mathrm{AU}$ volume $\%$ of the $\mathrm{AU}$

represents area $\%$ of the $\mathrm{AU}$

volume $\%$ of the $\mathrm{AU}$ volume $\%$ of the $\mathrm{AU}$

represents area $\%$ of the $\mathrm{AU}$

volume $\%$ of the $\mathrm{AU}$ volume $\%$ of the $\mathrm{AU}$

represents area $\%$ of the $A U$

volume $\%$ of the $\mathrm{AU}$ volume $\%$ of the $\mathrm{AU}$

represents area $\%$ of the $\mathrm{AU}$ volume $\%$ of the $\mathrm{AU}$ volume $\%$ of the $\mathrm{AU}$ 


\section{ALLOCATIONS OF POTENTIAL ADDITIONS TO RESERVES TO FEDERAL LAND SUBDIVISIONS Surface Allocations}

1. Bureau of Land Management (BLM) represents area $\%$ of the $\mathrm{AU}$

Oil in Oil Accumulations:

Gas in Gas Accumulations:

volume $\%$ of the $\mathrm{AU}$ volume $\%$ of the $A U$

2. BLM Wilderness Areas (BLMW) represents area $\%$ of the $\mathrm{AU}$

Oil in Oil Accumulations: volume $\%$ of the $\mathrm{AU}$

Gas in Gas Accumulations: volume $\%$ of the $\mathrm{AU}$

3. BLM Roadless Areas (BLMR) represents area $\%$ of the $\mathrm{AU}$

Oil in Oil Accumulations: volume $\%$ of the $\mathrm{AU}$

Gas in Gas Accumulations: volume $\%$ of the $\mathrm{AU}$

4. National Park Service (NPS) represents 0.00 area $\%$ of the $\mathrm{AU}$

Oil in Oil Accumulations: volume $\%$ of the $\mathrm{AU}$ Gas in Gas Accumulations: volume $\%$ of the $\mathrm{AU}$

5. NPS Wilderness Areas (NPSW) represents area $\%$ of the $\mathrm{AU}$

Oil in Oil Accumulations: volume $\%$ of the $\mathrm{AU}$ Gas in Gas Accumulations: volume $\%$ of the $\mathrm{AU}$

6. NPS Protected Withdrawals (NPSP) represents area \% of the $\mathrm{AU}$

Oil in Oil Accumulations: volume $\%$ of the $\mathrm{AU}$ Gas in Gas Accumulations: volume $\%$ of the $\mathrm{AU}$

7. US Forest Service (FS) represents 0.36 area $\%$ of the $\mathrm{AU}$

Oil in Oil Accumulations: Gas in Gas Accumulations:

8. USFS Wilderness Areas (FSW) represents area $\%$ of the $\mathrm{AU}$

Oil in Oil Accumulations: Gas in Gas Accumulations: volume $\%$ of the $\mathrm{AU}$

0.36 volume $\%$ of the $\mathrm{AU}$ 
Scenario (name, no.)

\section{ALLOCATIONS OF POTENTIAL ADDITIONS TO RESERVES TO FEDERAL LAND SUBDIVISIONS Surface Allocations}

9. USFS Roadless Areas (FSR) represents area $\%$ of the $\mathrm{AU}$

Oil in Oil Accumulations: volume $\%$ of the $\mathrm{AU}$

Gas in Gas Accumulations: volume $\%$ of the $\mathrm{AU}$

10. USFS Protected Withdrawals (FSP) represents area $\%$ of the $\mathrm{AU}$

Oil in Oil Accumulations: volume $\%$ of the $\mathrm{AU}$ Gas in Gas Accumulations: volume $\%$ of the $\mathrm{AU}$

11. US Fish and Wildlife Service (FWS) represents 0.02 area $\%$ of the $\mathrm{AU}$

Oil in Oil Accumulations: volume $\%$ of the $\mathrm{AU}$

Gas in Gas Accumulations: volume $\%$ of the $\mathrm{AU}$

12. USFWS Wilderness Areas (FWSW) represents area $\%$ of the $\mathrm{AU}$

Oil in Oil Accumulations: volume $\%$ of the $\mathrm{AU}$

Gas in Gas Accumulations: volume $\%$ of the $\mathrm{AU}$

13. USFWS Protected Withdrawals (FWSP) represents area $\%$ of the $\mathrm{AU}$

Oil in Oil Accumulations: volume $\%$ of the $\mathrm{AU}$ Gas in Gas Accumulations: volume $\%$ of the $\mathrm{AU}$

14. Wilderness Study Areas (WS) represents area \% of the $\mathrm{AU}$

Oil in Oil Accumulations: volume $\%$ of the $\mathrm{AU}$ Gas in Gas Accumulations: volume $\%$ of the $\mathrm{AU}$

15. Department of Energy (DOE) represents area $\%$ of the $\mathrm{AU}$

Oil in Oil Accumulations: volume $\%$ of the $\mathrm{AU}$ Gas in Gas Accumulations: volume $\%$ of the $\mathrm{AU}$

16. Department of Defense (DOD) represents $\quad 0.42$ area $\%$ of the $\mathrm{AU}$

Oil in Oil Accumulations: Gas in Gas Accumulations: volume $\%$ of the $\mathrm{AU}$ 0.42 volume $\%$ of the $\mathrm{AU}$ 


\section{ALLOCATIONS OF POTENTIAL ADDITIONS TO RESERVES TO FEDERAL LAND SUBDIVISIONS Surface Allocations}

17. Bureau of Reclamation (BOR) represents area $\%$ of the $\mathrm{AU}$

Oil in Oil Accumulations: volume $\%$ of the $\mathrm{AU}$

Gas in Gas Accumulations: volume $\%$ of the $A U$

18. Tennessee Valley Authority (TVA) represents area $\%$ of the $\mathrm{AU}$

Oil in Oil Accumulations: volume $\%$ of the $\mathrm{AU}$

Gas in Gas Accumulations: volume $\%$ of the $\mathrm{AU}$

19. Other Federal represents area $\%$ of the $\mathrm{AU}$

Oil in Oil Accumulations:

Gas in Gas Accumulations:

20.

Oil in Oil Accumulations:

Gas in Gas Accumulations: volume $\%$ of the $\mathrm{AU}$ volume $\%$ of the $\mathrm{AU}$

represents area $\%$ of the $\mathrm{AU}$

volume $\%$ of the $\mathrm{AU}$ volume $\%$ of the $\mathrm{AU}$ 


\section{ALLOCATIONS OF POTENTIAL ADDITIONS TO RESERVES TO ECOSYSTEMS Surface Allocations}

1. Blackland Prairies (BLPR) represents 18.87 area $\%$ of the $\mathrm{AU}$

Oil in Oil Accumulations: volume $\%$ of the $\mathrm{AU}$

Gas in Gas Accumulations: volume $\%$ of the $\mathrm{AU}$

2. Mid Coastal Plains, Western (MCPW) represents 8.53 area $\%$ of the $\mathrm{AU}$

Oil in Oil Accumulations: volume $\%$ of the $\mathrm{AU}$

Gas in Gas Accumulations: volume $\%$ of the $\mathrm{AU}$

3. Oak Woods and Prairies (OWPR) represents 44.24 area $\%$ of the $\mathrm{AU}$

Oil in Oil Accumulations: volume $\%$ of the $\mathrm{AU}$

Gas in Gas Accumulations: 44.24 volume $\%$ of the $\mathrm{AU}$

4. Rio Grande Plain (RGPL) represents 26.85 area $\%$ of the $\mathrm{AU}$

Oil in Oil Accumulations: volume $\%$ of the $\mathrm{AU}$

Gas in Gas Accumulations: 26.85 volume $\%$ of the $\mathrm{AU}$

5. Stockton Plateau (STPT) represents 1.51 area $\%$ of the $\mathrm{AU}$

Oil in Oil Accumulations: Gas in Gas Accumulations:

6.

Oil in Oil Accumulations: Gas in Gas Accumulations:

7.

Oil in Oil Accumulations: Gas in Gas Accumulations:

8.

Oil in Oil Accumulations: Gas in Gas Accumulations: represents area $\%$ of the $A U$ volume $\%$ of the $\mathrm{AU}$ volume $\%$ of the $A U$

represents area $\%$ of the $\mathrm{AU}$ volume $\%$ of the $\mathrm{AU}$ volume $\%$ of the $\mathrm{AU}$ represents area $\%$ of the $\mathrm{AU}$ volume $\%$ of the $\mathrm{AU}$ volume $\%$ of the $\mathrm{AU}$ 


\section{ALLOCATIONS OF POTENTIAL ADDITIONS TO RESERVES TO ECOSYSTEMS Surface Allocations}

9. represents area $\%$ of the $\mathrm{AU}$

Oil in Oil Accumulations: volume $\%$ of the $\mathrm{AU}$

Gas in Gas Accumulations: volume $\%$ of the $\mathrm{AU}$

10. represents area \% of the $\mathrm{AU}$

Oil in Oil Accumulations: volume $\%$ of the $\mathrm{AU}$

Gas in Gas Accumulations: volume $\%$ of the $\mathrm{AU}$

11. represents area $\%$ of the $\mathrm{AU}$

Oil in Oil Accumulations:

Gas in Gas Accumulations:

Oil in Oil Accumulations:

Gas in Gas Accumulations: represents area $\%$ of the $\mathrm{AU}$

volume $\%$ of the $\mathrm{AU}$ volume $\%$ of the $\mathrm{AU}$

volume $\%$ of the $\mathrm{AU}$ volume $\%$ of the $\mathrm{AU}$ 
Table 3. Input parameters for the Bossier Shale Continuous Gas Assessment Unit (50490163), Onshore U.S. Gulf Coast Province.

[Well production data from IHS Markit ${ }^{\mathrm{TM}}$ (2016). bcfg, billion cubic feet of gas; mmcfg, million cubic feet of gas; cfg, cubic feet of gas; mmbo, million barrels of oil; bo, barrel of oil; bliq, barrel of liquid; bngl, barrel of natural gas liquids; NGL, natural gas liquids; no., number; m, meter; AU, assessment unit; EUR, estimated ultimate recovery; IHS, IHS Markit; API, American Petroleum Institute; \%, percent; $\mathrm{CO}_{2}$, carbon dioxide; frac, hydraulic fracturing; BTU, British thermal unit] 
Assessment Geologist:

Region:

Province:

Total Petroleum System:

Assessment Unit:

Based on Data as of:

Notes from Assessor:

\section{IDENTIFICATION INFORMATION}

S.T. Paxton

North America

Gulf Coast Mesozoic

Upper Jurassic-Cretaceous-Tertiary Composite

Bossier Shale Continuous Gas

IHS (2016)
Date:

Number:

Number:

Number:

Number:

$\frac{\frac{20-O c t-16}{5}}{\frac{5049}{504901}} \frac{50490163}{5}$

Coproduct ratios and ancillary data from Haynesville Western Shelf AU 50490116

\section{CHARACTERISTICS OF ASSESSMENT UNIT}

Assessment-unit type:

$$
\begin{aligned}
& \text { oil }(<20,000 \mathrm{cfg} / \mathrm{bo}) \\
& \text { heavy oil }(<10 \mathrm{API})
\end{aligned}
$$

gas $(>20,000 \mathrm{cfg} / \mathrm{bo})$

$\mathrm{X}$

Well type:

vertical horizontal

$x$

Major reservoir type (Choose one.):

shale $\mathrm{x}$

low-permeability clastics low-permeability carbonates diatomite

Minimum EUR per well $\quad 0.02$ (mmbo for oil AU; bcfg for gas $\mathrm{AU}$ )

Number of tested wells: 266

Number of tested wells with EUR > minimum:

Historic success ratio, tested wells (\%)

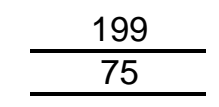

Assessment-Unit Probability:

What is the probability that at least one well within the AU will have production capacity of at least the minimum EUR?

\section{NUMBER OF UNDRILLED WELLS WITH POTENTIAL FOR ADDITIONS TO RESERVES}

1. Productive area of accumulation (acres): (triangular)

calculated mean $\underline{10,517,667}$ minimum $\underline{20,000}$ mode $\underline{5,612,000}$ maximum $\underline{25,921,000}$

2. Uncertainty about average drainage area of wells (acres): (triangular)

calculated mean

113

minimum

60

mode 100

maximum

180

3. Percentage of total assessment-unit area that is untested (\%): (triangular)

calculated mean

99.7

minimum

99.5

mode $\quad 99.7$

maximum

99.9

4. Percentage of untested assessment-unit area in sweet spots (\%): (triangular)

$$
\text { calculated mean }
$$

100

minimum

100

mode

100

maximum

100 


\section{ESTIMATED ULTIMATE RECOVERY (EUR) PER WELL \\ SWEET SPOTS}

5a. Future success ratio (\%): (triangular)

calculated mean

50

minimum

10

mode

50

maximum

90

5b. Uncertainty about average EUR (mmbo for oil; bcfg for gas): (shifted truncated lognormal)

calculated mean $\quad 1.109$

minimum

0.5

median

1

maximum

3

\section{NON-SWEET SPOTS}

6a. Future success ratio (\%): (triangular)

calculated mean

minimum

mode

maximum

6b. Uncertainty about average EUR (mmbo for oil; bcfg for gas): (shifted truncated lognormal)

calculated mean

minimum

median

maximum

\section{UNCERTAINTY ABOUT AVERAGE COPRODUCT RATIOS FOR UNTESTED WELLS}

(triangular)

Oil assessment unit:

Gas/oil ratio (cfg/bo)

NGL/gas ratio (bngl/mmcfg)

Gas assessment unit:

Liquids/gas ratio (bliq/mmcfg)
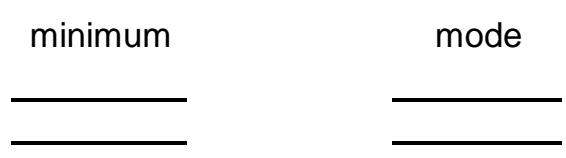

maximum

1

3

5 


\section{SELECTED ANCILLARY DATA FOR UNTESTED WELLS}

(no specified distribution type)

Oil assessment unit: API gravity of oil (degrees)

Sulfur content of oil (\%)

Depth (m) of water (if applicable)

Drilling depth $(\mathrm{m})$

Gas assessment unit: Inert-gas content (\%) $\mathrm{CO}_{2}$ content (\%)

Hydrogen sulfide content (\%)

Heating value (BTU)

Depth ( $m$ ) of water (if applicable)

Drilling depth $(m)$

$$
\text { minimum }
$$

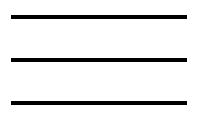

minimum median

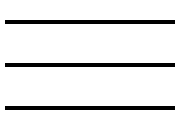

F75

median

F25

maximum

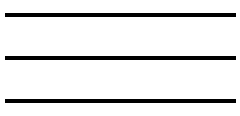

maximum

$\longrightarrow$

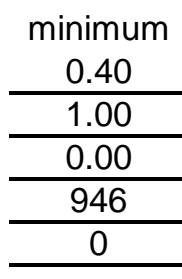

minimum

1500

\begin{tabular}{c}
$\begin{array}{c}\text { median } \\
1.00\end{array}$ \\
\hline 2.00 \\
\hline 0.10 \\
\hline 1020 \\
\hline 5 \\
\hline
\end{tabular}

F75

median 3800 maximum

5.00

3.00

0.60

1221

10

F25

maximum 5200

Completion practices:

1. Typical well-completion practices (conventional, open hole, open cavity, other)

2. Fraction of wells drilled that are typically stimulated

3. Predominant type of stimulation (none, frac, acid, other)

4. Historic fraction of wells drilled that are horizontal

conventional

1.00

frac. and acid

1.00 


\section{ALLOCATIONS OF POTENTIAL ADDITIONS TO RESERVES TO STATES Surface Allocations}

1. Louisiana

Onshore:

20.35 area $\%$ of the $\mathrm{AU}$

20.35 mean volume $\%$ of the $\mathrm{AU}$

Offshore:

area $\%$ of the $\mathrm{AU}$

mean volume $\%$ of the $\mathrm{AU}$

2. Mississippi

Onshore:

12.92 area $\%$ of the $\mathrm{AU}$

12.92 mean volume $\%$ of the $\mathrm{AU}$

Offshore: area $\%$ of the $\mathrm{AU}$ mean volume $\%$ of the $\mathrm{AU}$

3. Texas

Onshore:

66.73 area $\%$ of the $\mathrm{AU}$

66.73 mean volume $\%$ of the $\mathrm{AU}$

Offshore: area $\%$ of the $\mathrm{AU}$ mean volume $\%$ of the $A U$

4.

Onshore: area $\%$ of the $\mathrm{AU}$ mean volume $\%$ of the $A U$

Offshore: area $\%$ of the $\mathrm{AU}$ mean volume $\%$ of the $\mathrm{AU}$

5.

Onshore: area $\%$ of the $\mathrm{AU}$ mean volume $\%$ of the $A U$

Offshore: area \% of the $\mathrm{AU}$ mean volume $\%$ of the $A U$ 


\section{ALLOCATIONS OF POTENTIAL ADDITIONS TO RESERVES TO STATES}

(continued)

6.

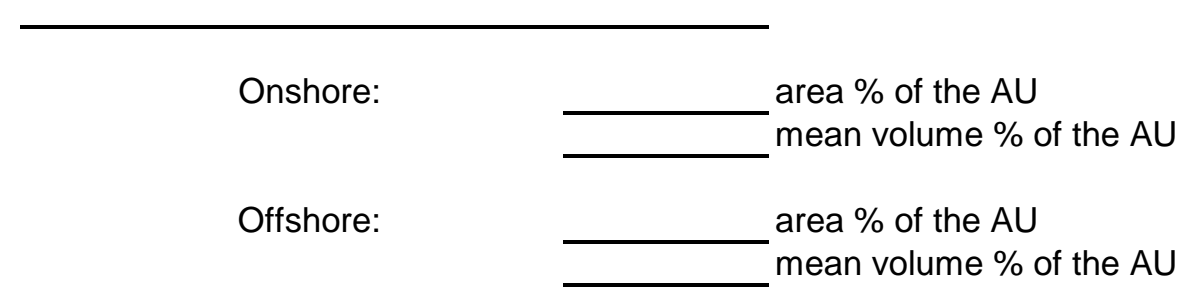

7.

Onshore:

Offshore:

Onshore:

Offshore:

Onshore:

Offshore:

Onshore:

Offshore: area $\%$ of the $\mathrm{AU}$

mean volume $\%$ of the $A U$

area $\%$ of the $\mathrm{AU}$

mean volume $\%$ of the $A U$

9

10.

of the $\mathrm{AU}$

mean volume $\%$ of the $\mathrm{AU}$

area $\%$ of the $\mathrm{AU}$

mean volume $\%$ of the $\mathrm{AU}$

(1)

mean volume $\%$ of the $A U$

area $\%$ of the $\mathrm{AU}$

mean volume $\%$ of the $\mathrm{AU}$

0. mean volume $\%$ of the $A U$ area $\%$ of the $\mathrm{AU}$ mean volume $\%$ of the $A U$ 


\section{ALLOCATIONS OF POTENTIAL ADDITIONS TO RESERVES TO PROVINCES Surface Allocations}

1. Number: 5049

Onshore:

Offshore:

2. Number:

Onshore:

Offshore:

3. Number:

4. Number:

Onshore:

Offshore:

Onshore:

Offshore:

5. Number:

Onshore:

Offshore:
Name: Gulf Coast Mesozoic

$\frac{100.00}{100.00}$ area $\%$ of the $\mathrm{AU}$
mean volume $\%$ of the $\mathrm{AU}$
area $\%$ of the $\mathrm{AU}$
mean volume $\%$ of the $\mathrm{AU}$

Name:

area $\%$ of the $\mathrm{AU}$

mean volume $\%$ of the $A U$

area $\%$ of the $\mathrm{AU}$

mean volume $\%$ of the $\mathrm{AU}$

Name:

area $\%$ of the $\mathrm{AU}$

mean volume $\%$ of the $\mathrm{AU}$

area $\%$ of the $\mathrm{AU}$

mean volume $\%$ of the $\mathrm{AU}$

Name:

area $\%$ of the $\mathrm{AU}$

mean volume $\%$ of the $A U$

area \% of the $\mathrm{AU}$

mean volume $\%$ of the $A U$

Name:

area $\%$ of the $\mathrm{AU}$

mean volume $\%$ of the $A U$

area $\%$ of the $\mathrm{AU}$

mean volume $\%$ of the $\mathrm{AU}$ 


\section{ALLOCATIONS OF POTENTIAL ADDITIONS TO RESERVES TO PROVINCES}

(continued)

6. Number:

Name:

Onshore:

Offshore:

area $\%$ of the $\mathrm{AU}$

mean volume $\%$ of the $A U$

area $\%$ of the $\mathrm{AU}$

mean volume $\%$ of the $\mathrm{AU}$

7. Number:

Name:

Onshore:

area $\%$ of the $\mathrm{AU}$

mean volume $\%$ of the $A U$

Offshore:

area $\%$ of the $\mathrm{AU}$

mean volume $\%$ of the $\mathrm{AU}$

8. Number:

Name:

Onshore:

area $\%$ of the $\mathrm{AU}$

mean volume $\%$ of the $\mathrm{AU}$

Offshore:

area $\%$ of the $\mathrm{AU}$

mean volume $\%$ of the $\mathrm{AU}$

9. Number:

Name:

Onshore:

area $\%$ of the $\mathrm{AU}$

mean volume $\%$ of the $A U$

Offshore:

area $\%$ of the $\mathrm{AU}$

mean volume $\%$ of the $A U$

10. Number:

Name:

Onshore:

area \% of the $\mathrm{AU}$

mean volume $\%$ of the $A U$

Offshore:

area $\%$ of the $\mathrm{AU}$

mean volume $\%$ of the $A U$ 


\section{ALLOCATIONS OF POTENTIAL ADDITIONS TO RESERVES TO GENERAL LAND OWNERSHIPS Surface Allocations}

1. Federal Lands

mean VOLUME \% in entity

2. Private Lands

mean VOLUME \% in entity

3. Tribal Lands

mean VOLUME \% in entity

4. Other Lands

mean VOLUME \% in entity

93.72

5. Louisiana State Lands

mean VOLUME \% in entity

0.46

6. Mississippi State Lands

mean VOLUME \% in entity

0.12

7. Texas State Lands

mean VOLUME \% in entity

0.13

8. Louisiana Offshore mean VOLUME \% in entity

0.47

9. Mississippi Offshore mean VOLUME \% in entity 0.92

10.

mean VOLUME \% in entity

.16 00 is

$4.02 \%$ of the AREA of the AU

is

$0.16 \%$ of the AREA of the AU

is

$0.00 \%$ of the AREA of the AU

is

$93.72 \%$ of the AREA of the AU

is

$0.46 \%$ of the AREA of the AU

is

$0.12 \%$ of the AREA of the AU

is

$0.13 \%$ of the AREA of the AU

is

$0.47 \%$ of the AREA of the AU

is

$0.92 \%$ of the AREA of the AU

is

$\%$ of the AREA of the AU 
ALLOCATIONS OF POTENTIAL ADDITIONS TO RESERVES TO GENERAL LAND OWNERSHIPS (continued)

11.

is

$\%$ of the AREA of the AU

mean VOLUME \% in entity

12.

mean VOLUME \% in entity

13.

mean VOLUME \% in entity

14.

mean VOLUME \% in entity

15.

mean VOLUME \% in entity

16.

mean VOLUME \% in entity

17.

mean VOLUME \% in entity

18.

mean VOLUME \% in entity

19.

mean VOLUME \% in entity

20.

mean VOLUME \% in entity is

$\%$ of the AREA of the AU

is $\%$ of the AREA of the AU

is $\%$ of the AREA of the AU

is $\%$ of the AREA of the AU

is $\%$ of the AREA of the AU

is $\%$ of the AREA of the AU

is $\%$ of the AREA of the AU

is $\%$ of the AREA of the AU

is $\%$ of the AREA of the AU 


\section{ALLOCATIONS OF POTENTIAL ADDITIONS TO RESERVES TO FEDERAL LAND SUBDIVISIONS Surface Allocations}

1. Bureau of Land Management (BLM) mean VOLUME \% in entity

2. BLM Wilderness Areas (BLMW) mean VOLUME \% in entity

3. BLM Roadless Areas (BLMR) mean VOLUME \% in entity

4. National Park Service (NPS) mean VOLUME \% in entity

5. NPS Wilderness Areas (NPSW) mean VOLUME \% in entity

6. NPS Protected Withdrawals (NPSP) mean VOLUME \% in entity

7. US Forest Service (FS) mean VOLUME \% in entity 2.95 0.00 is 0.00 $\%$ of the AREA of the AU $\%$ of the AREA of the AU

is $\%$ of the AREA of the AU

is $0.00 \%$ of the AREA of the AU

is $\%$ of the AREA of the AU $\%$ of the AREA of the AU

is $2.95 \%$ of the AREA of the AU

is $\%$ of the AREA of the AU

8. USFS Wilderness Areas (FSW) mean VOLUME \% in entity

9. USFS Roadless Areas (FSR) mean VOLUME \% in entity

10. USFS Protected Withdrawals (FSP) mean VOLUME \% in entity

is $\%$ of the ARE

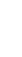




\section{ALLOCATIONS OF POTENTIAL ADDITIONS TO RESERVES TO FEDERAL LAND SUBDIVISIONS} (continued)

11. US Fish and Wildlife Service (FWS) mean VOLUME \% in entity

12. USFWS Wilderness Areas (FWSW) mean VOLUME \% in entity

13. USFWS Protected Withdrawals (FWSP) mean VOLUME \% in entity

14. Wilderness Study Areas (WS) mean VOLUME \% in entity

15. Department of Energy (DOE) mean VOLUME \% in entity

16. Department of Defense (DOD) mean VOLUME \% in entity

17. Bureau of Reclamation (BOR) mean VOLUME \% in entity

18. Tennessee Valley Authority (TVA) mean VOLUME \% in entity

19. Other Federal mean VOLUME \% in entity

20. mean VOLUME \% in entity is $\frac{0.31}{\%}$ of the AREA of the AU 0.31

is $\%$ of the AREA of the AU

is $\%$ of the AREA of the AU

is $\%$ of the AREA of the AU

is $\%$ of the AREA of the AU

is 0.75 $\%$ of the AREA of the AU 0.75

is $\%$ of the AREA of the AU

is $\%$ of the AREA of the AU

is $\%$ of the AREA of the AU

is $\%$ of the AREA of the AU 


\section{ALLOCATIONS OF POTENTIAL ADDITIONS TO RESERVES TO ECOSYSTEMS Surface Allocations}

1. Blackland Prairies (BLPR) mean VOLUME \% in entity

2. Coastal Plains and Flatwoods, Lower (CPFL) mean VOLUME \% in entity

3. Coastal Plains and Flatwoods, Western Gulf (CF mean VOLUME \% in entity 11.00

4. Coastal Plains, Middle (CPMD) mean VOLUME \% in entity 3.19

5. Louisiana Coast Prairies and Marshes (LCPM) mean VOLUME \% in entity 1.71

6. Mid Coastal Plains, Western (MCPW) mean VOLUME \% in entity 34.37

7. Mississippi Alluvial Basin (MABA) mean VOLUME \% in entity 4.06

8. Oak Woods and Prairies (OWPR) mean VOLUME \% in entity 23.61

9. Rio Grande Plain (RGPL) mean VOLUME \% in entity 11.66

10. mean VOLUME \% in entity is $0.88 \%$ of the AREA of the AU $8.12 \%$ of the AREA of the AU $11.00 \%$ of the AREA of the AU $3.19 \%$ of the AREA of the AU $1.71 \%$ of the AREA of the AU $34.37 \%$ of the AREA of the AU $4.06 \%$ of the AREA of the AU $23.61 \%$ of the AREA of the AU is $11.66 \%$ of the AREA of the AU is $\%$ of the AREA of the AU 


\section{ALLOCATIONS OF POTENTIAL ADDITIONS TO RESERVES TO ECOSYSTEMS}

(continued)

11.

is $\%$ of the AREA of the AU

mean VOLUME \% in entity

12.

mean VOLUME \% in entity

13.

mean VOLUME \% in entity

14.

mean VOLUME \% in entity

15.

mean VOLUME \% in entity

16.

mean VOLUME \% in entity

17.

mean VOLUME \% in entity

18.

mean VOLUME \% in entity

19.

mean VOLUME \% in entity

20.

mean VOLUME \% in entity is $\%$ of the AREA of the AU

is $\%$ of the AREA of the AU

is $\%$ of the AREA of the AU

is $\%$ of the AREA of the AU

is $\%$ of the AREA of the AU

is $\%$ of the AREA of the AU

is $\%$ of the AREA of the AU

is $\%$ of the AREA of the AU

is $\%$ of the AREA of the AU

Ecosystem allocations do not include offshore areas, hence the sum total $<100 \%$ 



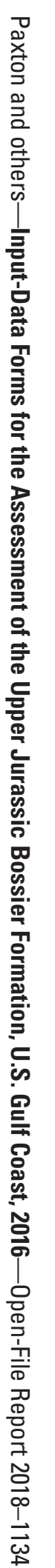

